\title{
Analysis on math success of secondary school students playing and not playing chess (Sakarya province sample)
}

\author{
Enes Iş1kgöz ${ }^{1}$
}

\begin{abstract}
The aim of this research is to analyze the contribution of the secondary level chess in the success of math lesson by comparing end-year math scores of the secondary school students playing and not playing chess. The research is a relational screening model and the research data are composed of end-year math scores in promotion sheets of the students. Thereby, the research group is composed of totally 274 students - 200 males and 74 females - studying at 5th, 6th, 7th and 8th grades in 5 secondary schools selected from the central districts of the city of Sakarya at the end of 2014-2015 school years. SPSS 22.0 statistical software package was used and the significance level was taken as $\mathrm{p}<0.05$. The obtained data was handled within the scope of descriptive and inferential statistics, and t-test and one-way analysis of variance (ANOVA) were used. A significant difference was found out between the end-year math scores of the students playing and not playing chess in favor of the playing ones. No significant difference was found between the endyear math scores of the students playing chess in relation to their genders and grades.
\end{abstract}

Keywords: Secondary school, chess, math Lesson, end-year success score

\section{Introduction}

The contribution of the sport in the development of cognitive domain along with the psychomotor and affective domains of the individuals is beyond all questions. Because, only when the mental development is coherent and balanced with the physical development, the individual and society can be healthy, long-lasting, happy, successful and efficient (Güçlü, 2001, p.1). Chess, which is both a mental game and a sports branch, takes an important place in the gain and development of cognitive abilities. As the chess has the main components such as being public, having the principle for accomplishment and carrying universal rules, being suitable for making organization with its competition feature and having results expressible with numbers, it is possible to regard chess game as a sports branch (Kulaç, 2009).

The game affects both the psychomotor, social and emotional development and the mental development of a child. Because, the game provides the child with opportunity to explore the world, get the required information and satisfy the sense of wonder (Çelik \& Şahin, 2013, p.471). With its history of 1500 years, the chess, which is both a game and a sports branch, contains activities which have rules and which are intellectual, competitive and recreational (Khosrorad, Kouhbanani \& Sani, 2014, p.284). The chess is accepted as a way in the direction of increasing the

\footnotetext{
${ }^{1}$ Asst. Prof. Dr., Batman University, School of Physical Education and Sports, Department of Physical Education and Sports Teacher, pdgenes@gmail.com
} 
Işıkgöz, E. (2016). Analysis on math success of secondary school students playing and not playing chess (Sakarya province sample). International Journal of Human Sciences, 13(1), 1689-1699. doi:10.14687/ijhs.v13i1.3693

children's mental encourage, concentration, memory and analytical skills (Ippolito, 2010, p.2). Owing to enhancing the memory and increasing quantitative skills with this aspect, the chess also improves problem solving abilities of the students. All over the world, many schools encourages playing chess in order to increase the academic performance (Kitsis, 2002, p.1). Because, the chess is a game of strategy. In this strategy, the chess plays an important role in gaining high level cognitive skills by the students with an effort for attaining the objective by setting the game much better, by defining potential responses in decision making and by realizing the self-guided learning (Wehmeyer et al., 2000, p.449). At the same time, the chess enhances scientific thinking. During the game, the chess players find out new ideas by setting many differences in their minds and develop their reading, memory, language and math skills (Dauvergne, 2000, p.1) by trying to guess the results (Ibrahim, 2014, p.34). The chess is also suggested as a teaching strategy in psychological aspect owing to promoting mental processes such as attention, memory, concentration, creativity and reasoning (Stewart, 2013; Saariluoma, 2001).

Reaching to concrete via abstract, attaining to complex structures via simple structures and making comments on them which are followed in producing and learning mathematical knowledge can be observed in the games played from child-hood up to the adulthood (Uğurel \& Moralı, 2008, p.83). One of the best motivation means that can be used by a good teacher is the educational games. This is because the children like games. The chess game, thus, ensures them to be voluntary for solving the problems and to expend time completely in logical thinking (Köksal, 2006, p.24). The general objectives of the curriculum of math lesson for 5th, 6th, 7th and 8th grades in secondary school in our country emphasize that the students can use their forecasting and mental processing abilities effectively, develop their problem solving strategies and use them in solving their daily problems and enhance their characteristics such as being systematic, careful, patient and responsible (Ministry of National Education [MEB], 2013, p.2). Again, in addition to bringing in mathematical concepts in the program, it is aimed to enhance the problem solving abilities for learning and using math affectively, mathematical processing skills, affective and psychomotor skills and other skills on knowledge and communication technologies (MEB, 2013, p.3).

The interests and attitudes of the students towards the math lesson have an important role in ensuring all these objectives and skills specified in the program gained by the students. Because, while the math lesson can be seen by the students as a lesson containing complex numerical processes and the solutions of questions requiring memorization as from the primary school, it is seen by some as entertaining and as one of the ways for comprehending the real life. One of the basic reasons of the difference between these attitudes is to comprehend or not comprehend (Öztürk \& Şahin, 2015, p.344). Both the national and international exam results show that a different way from the current system in math education should be followed and, thus, the individuals who associate math to the daily life and have reasoning and interpretation skills should be raised (Gökbulut \& Yumuşak, 2014, p.675). It is seen in the conducted researches that teaching with games in math lessons increases the success of the students. In a project study on "Mathematical Ability Education with Games" (Darüşşafaka Education Institutions, 2014), it is deducted that the games used in relation with the contribution in the development of mental abilities and the attitudes towards the math lesson increase the mathematical reasoning skills of the students, decrease their anxieties for math, and stand as motivating. In another research, it is observed that the students' attentions are drawn with the activities and games prepared for the purpose of apprehending simple four operation skills and they concentrate in the lesson much better, attend actively in the lesson and have higher motivations as they study with a group of friends with similar learning levels to themselves (Bintaş, 2007, p.444).

In this respect, the lesson mainly related with math is the chess. Because, math undertakes a function beyond teaching the numbers and bringing in the calculation skills and provides important 
Iş1kgöz, E. (2016). Analysis on math success of secondary school students playing and not playing chess (Sakarya province sample). International Journal of Human Sciences, 13(1), 1689-1699. doi:10.14687/ijhs.v13i1.3693

supports such as thinking, establishing relations be-tween the incidents, reasoning, forecasting and problem solving which ensure us to stand up in the struggle for survive that is getting more complicated each passing day (Umay, 2003, p.234). Math is a science of making someone think as being a science of wisdom and logic. The most important feature of math making it differ from the other sciences is to be wholly human-built (Işık, Çiltaş \& Bekdemir, 2008, p.177). Math has a great importance in terms of both social sciences and physical sciences, and there is a significant relationship between math and chess (Bilgili \& Dalkıran, 2004). In the chess game, the mathematical models, graph theory and various combinations are used just as in the problems (Gik, 1991).

It is found out in researches about the effect of chess on the success of math that the children playing chess have increased their successes. In a research conducted by International Herald Tribune ("Math Fear Checkmate", 2004), it was stated that playing chess for three hours was equal to studying math for two hours and a language lesson like Latin for two more hours. In the news which emphasized that the contribution of the chess in education was discovered again, it was ex-pressed that USA was the leading country bringing the chess into educational institutions, and it was observed in a study conducted in the country that the problem solving abilities of the students taking chess lessons increased at the rate of \%17.3. In addition, it was indicated that the math and chess lessons were given together in Canada and, thus, the students learnt math, such a difficult lesson, through game and they could succeed to solve problems mentally in a quicker way. Afterwards in the news, it was expressed that another country bringing chess into the lives of the students was China. It was emphasized that the chess was taught within a program in last few years in Chinese schools, and the teachers being good at playing chess were charged on the head of these programs. It is seen that playing chess at early ages assists to develop skills for math and critical thinking and there is a high direct proportion between the chess played in childhood and the academic success.

In "Curriculum and Guide for Primary School Chess Lesson" prepared by General Directorate of Primary Education, Ministry of National Education in order to be used in primary school chess trainings (MEB, 2006, p.8), considering the benefits of the chess, it is stated that there is an exact coherence with the general objectives of Turkish National Education and it can be used as a tool of education in attaining these objectives. In this respect, the emphasized point is that the major aim of the chess program is to assist the versatile development of the individual in mental and affective terms through the chess as in the other lessons. In the program, it is seen the results of the researches related with chess suggest that the chess enhancements in the mental capacities of the individuals playing it such as creativity, critical thinking, decision making and problem solving, and that the chess affects the success positively and it is a good sport in using the time well.

Negative attitude and thoughts, fears and anxieties related with math during the education are one of the common subjects on which the education researchers have studied intensively and will study further (Uğurel \& Moral, 2008, p.95). Today, math is no more a collection of abstract concepts and skills which are required to be learnt, but rather it is perceived as an information based on the modelling of the reality and arising as a result of the problem solving and interpretation process and as the abilities being developed within this process (Altun, 2006, p.226). With this research, it is aimed to find out the contribution of the chess in the success of math lesson by comparing end-year math scores of the secondary school students playing and not playing chess. In the research, it is seen as important to reveal the benefits of chess as an education tool in increasing the math success of the student on secondary school level. Within this context, the following questions are tried to be answered:

1- Is there any difference between the end-year math scores of the secondary school students playing and not playing chess? 
Iş1kgöz, E. (2016). Analysis on math success of secondary school students playing and not playing chess (Sakarya province sample). International Journal of Human Sciences, 13(1), 1689-1699. doi:10.14687/ijhs.v13i1.3693

2- Is there any difference between the end-year math scores of the students playing chess in relation to their genders and grades?

\section{Method}

This research is conducted with descriptive analysis method within relational screening method. The screening models are the research approaches aiming to describe a situation which was in existence in the past and still in existence as its current form, and thus, the incidents, individuals or objects mentioned in the research are tried to be described in their own conditions and as they are (Karasar, 2008). "Document review" method is used within the framework of qualitative research approach. The document review involves the analysis of written materials containing information about the phenomenon and facts aimed to be studied. The document analysis can also be used as a research method by itself (Yildırım \& Şimşek 2006).

The working group of the research is composed of totally 274 students - 137 students playing chess and studying at 5th, 6th, 7th and 8th grades in 5 secondary schools selected from the central districts of the city of Sakarya at the end of 2014-2015 school year, and 137 students not playing chess and selected with random method from these classes. In the research, the end-year math scores in promotion sheets of 274 students included in the working group in 2014-2015 school year are analyzed. Without indicating any personal identifying information; the gender, grades and endyear math scores in promotion sheets of the students playing chess and the end-year math scores in promotion sheets of the randomly selected students who do not play chess and are in the same class with the abovementioned first group are obtained from the administrations of the schools included in the research group. In order to obtain reliable results in the research, an attention is paid for the equality in the number of the students playing and not playing chess. As the promotion sheet has an official characteristic, the obtained data is accepted as valid and reliable.

In the analysis of the obtained data, the statistical package program SPSS 22.0 (Statistical Package for Social Sciences) is used and the level of significance is found as $p<0.05$. The data is dealt within the framework of descriptive and deductive statistics. In this framework, firstly the frequencies and percentage distributions of gender, grades and end-year math scores of the students playing and not playing chess are dealt. $T$ test in accordance with the variable of gender is used in the comparison of the end-year scores of the students and the one-way analysis of variance (ANOVA) is used for the variable of grade. The obtained findings are presented in graphics and tables.

\section{Results}

The data on the gender and grades of the students playing and not playing chess are presented in Table 1.

Table 1

Data on the gender and grades of the student group included in the research

\begin{tabular}{lcccccc}
\hline & \multicolumn{2}{c}{ Playing } & Chess & \multicolumn{2}{c}{$\begin{array}{c}\text { Not Playing } \\
\text { Chess }\end{array}$} & \multicolumn{2}{c}{ Total } \\
\hline Gender & \multicolumn{1}{c}{$\boldsymbol{f}$} & $\boldsymbol{\%}$ & $\boldsymbol{f}$ & $\boldsymbol{\%}$ & $\boldsymbol{f}$ & $\boldsymbol{\%}$ \\
\hline Male & 100 & 73.0 & 100 & 73.0 & 200 & 73.0 \\
Female & 37 & 27.0 & 37 & 27.0 & 74 & 27.0 \\
\hline Grade & $\boldsymbol{f}$ & $\boldsymbol{\%}$ & $\boldsymbol{f}$ & $\boldsymbol{\%}$ & $\boldsymbol{f}$ & $\boldsymbol{\%}$ \\
\hline $5^{\text {th }}$ Grade & 39 & 28.5 & 39 & 28.5 & 78 & 28.5 \\
$6^{\text {th }}$ Grade & 40 & 29.2 & 40 & 29.2 & 80 & 29.2 \\
$7^{\text {th }}$ Grade & 32 & 23.4 & 32 & 23.4 & 64 & 23.4 \\
$8^{\text {th }}$ Grade & 26 & 19.0 & 26 & 19.0 & 52 & 19.0 \\
\hline Total & $\mathbf{1 3 7}$ & $\mathbf{1 0 0 . 0}$ & $\mathbf{1 3 7}$ & $\mathbf{1 0 0 . 0}$ & $\mathbf{2 7 4}$ & $\mathbf{1 0 0 . 0}$ \\
\hline
\end{tabular}


Iş1kgöz, E. (2016). Analysis on math success of secondary school students playing and not playing chess (Sakarya province sample). International Journal of Human Sciences, 13(1), 1689-1699. doi:10.14687/ijhs.v13i1.3693

According to Table 1, equal numbers of students are taken into the context of research from both gender and grade groups. While 100 of the students $(73 \%)$ playing and not playing chess are male, the other 37 students $(27 \%)$ are female. When the data in Table 1 are analyzed, it is seen that male students play much more chess than the females. According to the grades; 39 of the students $(28.5 \%)$ are at $5^{\text {th }}$ grade, 40 students $(29.2 \%)$ at $6^{\text {th }}$ grade, 32 students $(23.4 \%)$ at $7^{\text {th }}$ grade, and 26 students $(19.0 \%)$ at $8^{\text {th }}$ grade. The descriptive statistical results related with the distribution of the end-year math scores of these students are given in Table 2.

Table 2

Descriptive statistical results of the end-year math scores of the students playing and not-playing chess

\begin{tabular}{|c|c|c|c|}
\hline & & $\begin{array}{c}\text { Distribution of end-year scores of } \\
\text { the students playing chess }\end{array}$ & $\begin{array}{l}\text { Distribution of end-year scores of } \\
\text { the students not playing chess }\end{array}$ \\
\hline \multirow[t]{2}{*}{$\overline{\mathrm{N}}$} & Valid & 137 & 137 \\
\hline & Null & 0 & 0 \\
\hline \multicolumn{2}{|c|}{ Mean } & 86.4235 & 64.3101 \\
\hline \multicolumn{2}{|c|}{ Standard deviation } & 11.04798 & 15.93893 \\
\hline \multicolumn{2}{|c|}{ Variance } & 122.058 & 254.050 \\
\hline \multicolumn{2}{|c|}{ Minimum } & 48.00 & 32.30 \\
\hline \multicolumn{2}{|c|}{ Maximum } & 100.00 & 97.00 \\
\hline
\end{tabular}

According to Table 2, while the average of the end-year math scores of the students playing chess is 86.4235 , it is 64.3101 for the ones not playing chess. The minimum math score of the students playing chess is 48.00 and the maximum score is 100.00 . For the students' not playing chess, while the minimum math score is 32.30 , the maximum score is 97.00 . The average of the end-year scores of the students playing and not playing chess according to the grades is shown in Figure 1.

Figure 1. Mean of the end-year scores of the students playing and not playing chess according to the grades

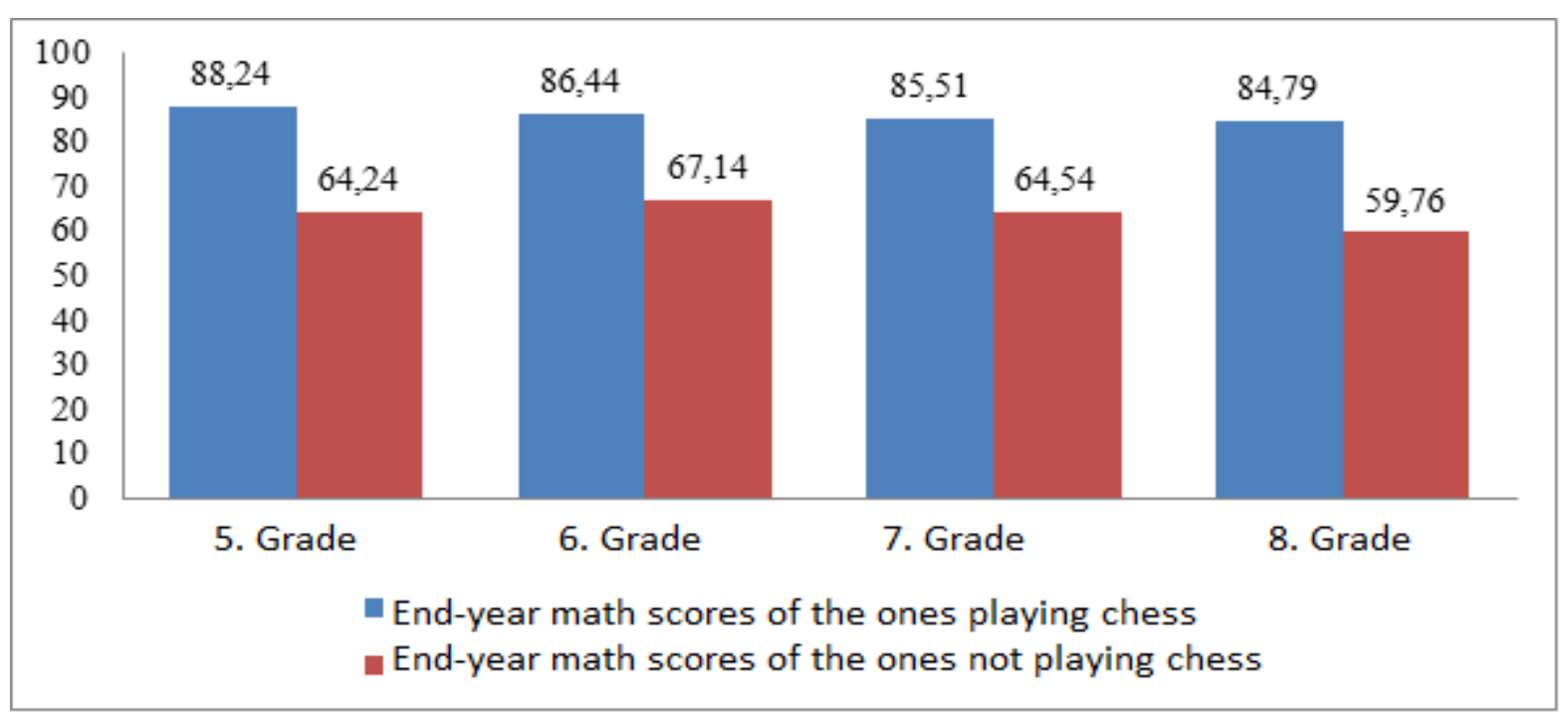


Iş1kgöz, E. (2016). Analysis on math success of secondary school students playing and not playing chess (Sakarya province sample). International Journal of Human Sciences, 13(1), 1689-1699. doi:10.14687/ijhs.v13i1.3693

When the graphic shown in Figure 1 is reviewed, it is observed that the highest average in the end-year math scores in the group of the students playing chess belongs to $5^{\text {th }}$ grade students with an average of 88.24 , and the lowest average is seen at $8^{\text {th }}$ grade students with an average of 84.79. The $6^{\text {th }}$ grade students come in second and $7^{\text {th }}$ grade students come in third with averages of 86.44 and 85.51 respectively. A small decrease is observed in the end-year math scores of the student group playing chess as it is passed to an upper grade. The reasons of this decrease are thought that the interests of the students in chess decline along with the increasing age, they tend towards other sportive and technological games and they prepare much more exam-oriented as they get higher grades.

The fact that the maximum number of students in the group of students playing chess is at $6^{\text {th }}$ grade with 40 students and the minimum number at $8^{\text {th }}$ grade with 26 students and that the number of the students decreases when they get higher grades are the indicator of the decline of the interest in chess. When the data in the graphic is reviewed, it is seen that the average of the end-year math scores of students playing chess is between 84 and 88 at the whole grade level. This score range is an important for the success of math lesson. On the other side, when the endyear math scores of the student group not playing chess, it is observed that the scores show up as 64.24 at $5^{\text {th }}$ grade, 67.14 at $6^{\text {th }}$ grade, 64.54 at $7^{\text {th }}$ grade and 69.76 at $8^{\text {th }}$ grade, and that the endyear math scores of the students group not playing chess are lower than the scores of the students group playing chess.

Table 3

Results of t test conducted to determine whether the end-year math scores of the students differ with respect to chess playing status

\begin{tabular}{cccccc}
\hline $\begin{array}{c}\text { End-year math } \\
\text { scores }\end{array}$ & $\boldsymbol{N}$ & $\boldsymbol{M}$ & $\boldsymbol{S D}$ & $\boldsymbol{t}$ & $\boldsymbol{P}$ \\
\hline Playing Chess & 137 & 86.4235 & 11.04798 & 13.346 & $.00 *$ \\
Not Playing Chess & 137 & 64.3101 & 15.93893 & & \\
\hline
\end{tabular}

As a result of $t$ test conducted to determine whether there is a difference between the endyear math scores of the students playing and not playing chess presented in Table 3, a significant difference in favor of the students group playing chess is seen ( $\mathrm{t}(272)=13,346, \mathrm{p}=.00)$. The mean of the end-year math scores of the students group playing chess are 22 points higher than the mean of the students not playing chess.

Table 4

Results of $t$ test conducted to determine whether the end-year math scores of the students differ with respect to gender variable

\begin{tabular}{cccccc}
\hline Gender & $\boldsymbol{N}$ & $\boldsymbol{M}$ & $\boldsymbol{S D}$ & $\boldsymbol{t}$ & $\boldsymbol{p}$ \\
\hline Male & 100 & 86.6265 & 11.34798 & 0.352 & .71 \\
Female & 37 & 85.8749 & 10.32220 & & \\
\hline
\end{tabular}

According to the data given in Table 4, no significant difference is found out between the end-year math scores of the students playing chess with respect to the gender variable $(\mathrm{t}(135)=0,352, \mathrm{p}=.71)$. 
Iş1kgöz, E. (2016). Analysis on math success of secondary school students playing and not playing chess (Sakarya province sample). International Journal of Human Sciences, 13(1), 1689-1699. doi:10.14687/ijhs.v13i1.3693

Table 5

One-Way Analysis of Variance of the end-year math scores of the students playing chess with respect to the grade variable

\begin{tabular}{lcccccc}
\multicolumn{1}{c}{ Grade } & Source & $\boldsymbol{d f}$ & $\boldsymbol{S S}$ & $\boldsymbol{M S}$ & $\boldsymbol{F}$ & $\boldsymbol{P}$ \\
\hline $5^{\text {th }}-6^{\text {th }}$-7th and $8^{\text {th }}$ & Between groups & 3 & 224.174 & 74.725 & 0.607 & .67 \\
Grade & Within groups & 133 & 16375.684 & 123.125 & & \\
\hline & Total & 136 & 16599.858 & & & \\
\hline
\end{tabular}

According to Table 5, no significant difference is observed between the end-year math scores of the students playing chess with respect to the grade variable $(F(136)=0.607, p=.67)$.

\section{Discussion and Conclusion}

In this research, the effect of chess in the success of math lesson is analyzed by comparing the end-year math scores of the students, who play and do not play chess, at secondary school level. As a result of the research, a significant difference between the end-year scores of the students in favor of the ones playing chess is found. However, no significant difference between the end-year scores of the students playing chess with respect to their genders and grades is found. The result obtained from the research matches up with the results of many researches in the literature. In the study conducted in this subject by Kazemi, Yektayar \& Abad, 2012; Barrett \& Fish, 2011; Hong \& Bart, 2007; it is seen that the chess enhances the mathematical skills of the students and increases their successes significantly. In the study by Erhan, Hazar \& Tekin (2009) on "Analysis of Problem Solving Skills of Primary School Students Playing and Not Playing Chess", while the hasty and avoidant approach level of the students not playing chess is found higher than the ones playing chess, the planned approach level of the students playing chess is seen much higher in comparison with the ones not playing chess.

In a research conducted on the students studying in quantitative departments in a university in China, it is seen that an increase of approximately 15\% in the results of the math and science lessons of the students taking chess lessons is provided (Bilgili \& Dalkıran, 2004). In a study by Liptrap (1998) on "Chess and Standard Test Scores", it is stated that the chess taught at between 2nd and 7th grades within math curriculum in New Brunswick, Canada increased the problem solving successes of the students in math subjects, where a difficulty is experienced, from $62 \%$ to $81 \%$, and that the chess increase the success of the primary school students by enhancing their math skills. In a study conducted by Romano (2011) in Italian schools with the question of "Does playing chess develop learning math?", it is concluded that the success of the students taught chess is increased on the ratio of one-third in comparison with the other students. In the study titled "Development of Critical and Creative Thinking through Chess" in USA by Ferguson (1995), known with important researches in the field, and conducted on 7th, 8th and 9th grade students; it is seen that the creative and critical thinking skills of the students taking chess lessons are found much higher. It is also stated by McDonald (2012) in a research conducted in 1994-1995 school year in 68 state schools within Bronx Region that an increase of 11.2/ in reading scores and 18.6\% in math scores of the students taken in chess trainings is provided.

In the study of Dauvergne (2010), it is stated that the productivity of the students who systematically taught with chess training increases much more than the ones who are not provided with chess trainings. The results suggesting that a significant difference between the pretest and posttest scores of 41 students provided with chess training occurs, and that the problem solving skills of the students after the chess training is enhanced are obtained in the study conducted by Razvani \& Fadaee (2014) searching the effect of the training of chess on the mathematical problem 
Iş1kgöz, E. (2016). Analysis on math success of secondary school students playing and not playing chess (Sakarya province sample). International Journal of Human Sciences, 13(1), 1689-1699. doi:10.14687/ijhs.v13i1.3693

solving skills of the primary school students. They suggest as a result of the study that the teachers can use the chess in the curriculum program as a tool. In the research conducted by Margulies (1991), it is emphasized that the chess has a positive effect on the reading scores and that the reading skills of the ones playing chess increase. In a case study carried out by Eberhard (2006) on the relationship between the chess training and the quantitative problem solving skills of the economically disadvantaged students, it is presented that the quantitative skills of the students can be improved by focusing on the disadvantaged students, with low math scores, through chess training.

In order to analyze the cognitive effects of chess on the education in a quasi-experimental study conducted by Aciego, Garcia \& Betancourt (2012) on a group of students between the ages of 6-16 taking and not taking chess training by using (WISC-R) intelligence scale, the problem solving skills of the student group taking chess lesson are found significant in comparison with the other group, and a result suggesting that the chess is a valuable educational appliance is obtained. In another study by Smith \& Cage (2000) conducted on the effect of the chess on the success of math and applied in an experimental group composed of 11 female and 10 male high school students and in an control group composed of 10 female and 10 male high school students; they find out that a significant difference is occurred between the pre-test and post-test scores of the experimental group taking a chess training of 120 hours.

Again, a similar study is conducted by Trinchero (2013) in Italy. In this study the effect of the chess training on the math skills of the primary school students is analyzed and 568 students are divided into four groups, two for experimental group and the other two for control group. The students included in the experimental groups take chess lessons along with their class lessons, and the students in control groups take just the class lessons. A significant difference in the scores of the math test applied to experimental groups taking chess trainings is provided and it is seen that the problem solving skills of the students are developed. In a study by Sala, Gorini \& Pravettoni (2015) on 560 students, between 8-11 ages, divided as control and experiment group, it is concluded that a strong correlation between the chess and math scores of the students of experiment group provided with online chess training, and that these students show a higher development in math and that even a chess training provided in a short period develops the mathematical skills of the students. In a postgraduate thesis study conducted by Sadık (2006) and titled "Comparison of the natural numbers-related story problems and the problem solving successes of 4th and 5th grade students who know playing chess and do not know", it is seen that the natural numbers-related problem solving skills of the 4th and 5th grade students playing chess are much higher. Scholz et al. (2008) conduct a research on the children with learning disability, and in a framework of a program in the schools, the students of the experiment group take one hour of their weekly math lessons as chess lesson and the students in control group take only their weekly math lessons. In the comparison carried out at the end of the year, it is seen that an increase in the calculation skills and concentrations of the students included in the experiment group is ensured.

Considering the result of both this research and the other studies in the literature, an increase in the learning abilities of the students playing chess is observed. It is thought that the problem solving skills of the students playing chess is developed as it contains a mental process, and thus this situation reflects positively on the math knowledge and skills of the students. The students are required to be encouraged for learning and playing chess in order to develop a positive attitude towards math lesson and to get the desired success by displaying a good performance in math lesson. In the meantime, using chess as an effective teaching method by associating it with the math lesson will contribute in the learning process of the lesson. As a result of this research, the following suggestions are bought forward: 
Iş1kgöz, E. (2016). Analysis on math success of secondary school students playing and not playing chess (Sakarya province sample). International Journal of Human Sciences, 13(1), 1689-1699. doi:10.14687/ijhs.v13i1.3693

1- This research conducted on secondary school level can be carried out on all educational levels on much broader student groups.

2- This research conducted within the context of math lesson can be done on the other lessons in an attempt to observe the results.

3- Especially the students with poor quantitative skills can be ensured to learn and play chess by directing them to elective chess lesson in primary school.

4- The culture of playing chess in schools can be developed within programs.

5- A place can be sometimes given for the chess game within math lessons.

6- Certain incentives can be provided for the math teachers to learn chess.

\section{References}

Aciego R., Garcia L., Betancourt M. (2012). The benefits of chess for the intellectual and socialemotional enrichment in school children. The Spanish Journal of Psychology, 15 (02), 551-559. doi:10.5209/rev_SJOP.2012.v15.n2.38866.

Altun, M. (2006). Matematik öğretiminde gelişmeler [Developments in math teaching]. Uludăg University Faculty of Education Journal, 19 (2), 223-238.

Barrett, D.C., \& Fish W.W. (2011). Our move: using chess to improve math achievement for students who receive special education services. International Journal of Special Education, 26 (3), 181-193.

Bilgili, A.E., \& Dalkıran, H.S. (2004). Üstün yetenekli çocuklarm eğitimi ve satranc [Training of the Gifted Children and Chess]. İstanbul: Çocuk Vakfi Yayınları.

Bintaş, J. (2007). Matematikte öğrenme güçlügü olan öğrenciler için matematik eğitimi [Teaching mathematics to low achieving elementary students]. e-Journal of New World Sciences Academy, 2 (4), 439-450.

Çelik, A., \& Şahin, M. (2013). Spor ve çocuk gelişimi [Sports and child development]. International Journal of Social Science, 6 (1), 467-478.

Darüşşafaka Eğitim Kurumları. (2014). Oyunlarla matematiksel beceri eğitimi üzerine bir araştırma [A research on mathematical skill training through games]. Retrieved July 21, 2015, from http://www.darussafaka.k12.tr/wp-content/uploads/2014/04/PROJE-47-Oyunlarlamatematiksel -Beceri-E $\%$ C4\% $\%$ Fitimi- $\% \mathrm{C} 3 \%$ C Czerine-Bir-Ara $\% \mathrm{C} 5 \% 9 \mathrm{Ft} \% \mathrm{C} 4 \% \mathrm{~B} 1 \mathrm{rma}$.pdf

Dauvergne, P. (2000). The case for chess as a tool to develop our children's minds. Retrieved June 14, 2015 from http://www.auschess.org.au/articles/chessmind.htm

Eberhard, J. W. (2006). A case study on the relationship between classroom chess instruction and nonverbal problem-solving abilities of economically disadvantaged students. In Redman, T. (Ed.), Chess and education: Selected essays from the Koltanowski Conference, 27-48, Richardson, The University of Texas at Dallas.

Erhan, E., Hazar, M., \& Tekin, M. (2009). Satranç oynayan ve oynamayan ilköğretim öğrencilerinin problem çözme becerilerinin incelenmesi [Investigation of the problem solving skills of primary school students that are playing chess or not]. Atatïrk University Journal of Physical Education and Sport Sciences, 11(2):1-8.

Ferguson, R. (1995). Chess in education research summary. Retrieved September 10, 2015, from http://www.scholasticchess.mb.ca/docs/ciers.pdf

Hong S. \& Bart W. M. (2007). Cognitive effects of chess instruction on students at risk for academic failure. International Journal of Special Education, 22 (3), 89-96.

Gik, J.E. (1991). Schach und mathematik. Deutsch: Deutsch Harri GmbH 
Iş1kgöz, E. (2016). Analysis on math success of secondary school students playing and not playing chess (Sakarya province sample). International Journal of Human Sciences, 13(1), 1689-1699. doi:10.14687/ijhs.v13i1.3693

Gökbulut, Y., \& Yumuşak, E.Y. (2014). Oyun destekli matematik öğretiminin 4. sınıf kesirler konusundaki erişi ve kalıcilığa etkisi [The effects of game-supported mathematics learning unit of fractions of 4 . grade achievement and permanence]. International Periodical for The Languages, Literature and History of Turkish or Turkic, 9 (2), 673-689.

Güçlü, M. (2001). Avrupa, Amerika Birleşik Devletleri, Çin ve Türkiye'de beden eğitimi ve sporun gelissimi [Development of Physical Training and Sports in Europe, United States of America, China and Turkey]. National Education Journal, 150.

Ippolito, D.J. (2010). Benefits of chess for children. Retrieved April 27, 2015, from http://nmchess.dyndns.org/ChessBenefitsOverview.pdf

Işık, A., Çiltaş, A., \& Bekdemir, M. (2008). Matematik eğitiminin gerekliliği ve önemi [The importance and necessity of mathematics education] Atatürk University Kazım Karabekir Faculty of Education Journal, 17, 174-184.

İbrahim, M. (2014). Benefits of playing chess and its applications in education. International Journal of Humanities, Arts, Medicine and Sciences, 2 (11), 31-36.

Karasar, N. (2008). Bilimsel araștrma yöntemi [Scientific research methods] Ankara: Nobel Yayın Dağıtım.

Kazemi F., Yektayar M., \& Abad., M.A. (2012). Investigation of the impact of chess play on developing meta-cognitive ability and math problem-solving power of students at different levels of education. 4th International Conference of Cognitive Science (ICCS 2011) Procedia, Social and Behavioral Sciences, 32, 372-379.

Khosrorad, R., Kouhbanani, S.S., \& Sani, A.R. (2014). Chess training for improving executive functions and mathematics performance of students with mathematics disorders. International Journal of Educational Investigations, 1 (1), 283-295.

Kitsis, A. (2002). Benefits of chess for academic performance and creative thinking. Retrieved July 30, 2015, from: www.vivacityinc.com/chess

Kulaç, O. (2009). Satranç ve spor [Chess and sports]. Retrieved October 11, 2015, from http://www.satranc.net/index.php/satranc/satranca-dair/makaleler/127-satranc-ve-spor

Köksal, A. (2006). Eğitimde satranç [Chess in Training]. Mebmet Akif Ersoy University Faculty of Education Journal, 12, 17-27

Liptrap, J. M. (1998). Chess and standard test scores, Chess Life, 41-43. Retrieved April 17, 2015, from http://chess.jliptrap.us/taas4.pdf

McDonald, P. S. (2012). The benefits of chess in education. Retrieved August 04, 2015, from http://www.psmcd.net/otherfiles/BenefitsOfChessInEdScreen2.pdf

Margulies, S. (1991.). The effect of chess on reading scores: District nine chess program. Second year report. NY: American Chess Foundation. Retrieved August 28, 2015, from http://www.givewell.net/files/Analysis/margulies.pdf

Matematik korkusu mat [Math Fear Checkmate]. (2004, February 24). Sabah Gazetesi Dış Haberler.

Ministry of National Education [MEB]. (2006). İlköğretim (1- 8. sinıflar) satranç dersi öğretim programı ve k1lavuzu [Curriculum and Guide for Primary School (1st - 8th Grades) Chess Lesson] Ankara.

Ministry of National Education [MEB]. (2013). Ortaokul matematik dersi (5, 6, 7 ve 8. sinuflar) ögrretim programı [Curriculum for Secondary School (5th, 6th, 7th and 8th Grades) Math Lesson]. Ankara.

Razvani, M.A. \& Fadaee, M.R. (2014). Effect of chess training on math problem-solving ability of elementary school students. Journal of Applied Environmental and Biological Sciences, 4 (5), 240244. 
Iş1kgöz, E. (2016). Analysis on math success of secondary school students playing and not playing chess (Sakarya province sample). International Journal of Human Sciences, 13(1), 1689-1699. doi:10.14687/ijhs.v13i1.3693

Romano, B. (2011). Does playing chess improve math learning? Promising (and inexpensive) results from Italy (Research Paper Graduate School of Education, University of Pennsylvania, USA). Retrieved June 21, 2015, from http://www.europechesspromotion.org/ upload/pagine /doc/SAM_research_synthesis.pdf

Sala, G., Gorini, A., \& Pravettoni, G. (2008). Mathematical problem-solving abilities and chess: an experimental study on young pupils. SAGE Open, 1-9. doi: 10.1177/2158244015596050

Saariluoma, P. (2001). Chess and content-oriented psychology of thinking. Psicológica, 22, 143-164.

Sadık, R. (2006). İlkögrretim 4. ve 5. simı satranç bilen ögrrenciler ile satranç bilmeyen öğrencilerin doğal saynlara iliskin dört işlem ve problem çözme başarlarmm karşılaștınlması [Comparison of the natural numbers-related story problems and the problem solving successes of 4th and 5th grade students who know playing chess and do not know]. Unpublished Master's Thesis, Abant İzzet Baysal University, Bolu.

Scholz, M., Niesch, H., Steffen, O., Ernst, B., Markus, L., Witruk, E. \& Schwarz, H. (2008). Impact of chess training on mathematics performance and concentration ability of children with learning disabilities. International Journal of Special Education, 23 (3), 138-148.

Smith J. P., \& Cage B. N. (2000). The effects of chess instruction on the mathematics achievement of southern, rural, black secondary students. Research in the Schools, 7 (1), 19-26.

Stewart, W. (2013). Chess psychology the WILL to WIN!, everyman chess. Retrieved July 13, 2015, from: https://www.newinchess.com/Shop/Images/Pdfs/7271.pdf

Trinchero R. (2013). Can chess training improve Pisa scores in mathematics? Retrieved August 11, 2015, from http://www.kcfe.eu/sites/default/files/Trinchero KCFE.pdf

Uğurel, I., \& Moralı, S. (2008). Matematik ve oyun etkileşimi [The interaction of mathematics \& game]. Gazi Faculty of Education Journal, 28 (3), 75-98.

Umay, A. (2003). Matematiksel muhakeme yeteneği [Mathematical reasoning ability]. Hacettepe University Faculty of Education Journal, 24, 234-243.

Öztürk, Y., \& Şahin, Ç. (2015). Matematiğe ilişkin akademik başar1-özyeterlilik ve tutum arasındaki ilişkilerin belirlenmesi [Determining the relationships between academic achievement, selfefficacy and attitudes towards math]. International Journal of Social Science, 31, 343-366. doi:10.9761/JASSS2621.

Wehmeyer, M., Palmer, S., Agran, M., Mithaug, D., \& Martin, J. (2000). Teaching students to become causal agents in their lives-the self-determining learning model of instruction. Exceptional Children June, 66, 439-453.

Yıldırım, A., \& Şimşek, H. (2006). Sosyal bilimlerde nitel araștırma yöntemleri [Qualitative research methods in social sciences]. Ankara: Seçkin Yayıncllk. 